\title{
ERRORS IN CONSECUTIVE INTERPRETING: A CASE OF JESSICA KUMALAWONGSO'S COURT
}

\author{
Putri Pridani Malau, Syahron Lubis, Umar Mono \\ Universitas Sumatera Utara, Medan, Indonesia \\ E-mail: putripridani8@gmail.com
}

Received: 2020-06-30

Accepted: 2021-02-26

\begin{abstract}
This study aimed to analyze the main types of errors found in the consecutive interpreting $(\mathrm{Cl})$ in Jessica Kumalawongso's trial court and to indicate its causes. The research method used is the descriptive qualitative method by means of the secondary data taken from Kompas TV, uploaded on YouTube in 2016 consisting of three videos of the justifications of Jessica's attorney, toxicologist and forensic pathologist before the interpreter in order to counter the public prosecutor in the courtroom. They were, then, classified into both the source and the target languages by analyzing their types of error leading to the finding of the main types and subtypes of errors. The result of this study is that based on Gonzales theory on the consecutive interpreting, 67 errors with six out of eight main types are found at the entire selected videos. The six main types of errors detected in the court proceedings are non-conservation of paralinguistic features, inadequate language proficiency, addition, omission, distortion and register conservation.
\end{abstract}

Keywords: Consecutive interpreting, Source Language, Non-conservation of Paralinguistic Features, Inadequate Language Proficiency

\section{Introduction}

Interpreting is, basically, the flow of rendering information and ideas from one language into another one verbally and consequently, the spoken words turn to be the pivotal concern for interpreters. Bao ( 1997) strengthens this concept that it refers to conveying the meaning of spoken words from one language to another orally either to an individual or to a group. Furthermore, Russell ( 2005) puts forward the theory that in terms of consecutive interpreting and its process can be explained after the signer or speaker has completed one or more ideas in the source language and then pauses while the interpreter transmits that information. There are two kinds of situation of the processes: interpreter listening to the source language's speaker and the sentences, and the part of speech being reproduced according to the audiences or the target language. $\mathrm{Cl}$ is essentially a recreation of meaning of the information given by a speaker.

Jessica Kumalawongso's case is assumed to have something to do with the erroranalysis interpretation and, therefore, it is worthwhile to be investigated. The interpretation of the justification and inquiries during the trial among those from the source language and the other ones from the target language along with the interpreter serving as the connector are inevitable. The report of Myrna's autopsy (the victim) apparently evinced the existence 
Errors in Consecutive Interpreting: A Case of Jessica Kumalawongso's Court, Putri Pridani Malau, Syahron Lubis, Umar Mono

of corrosive substances in her stomach damaging the gastric mucosa. Later, it was allegedly derived from cyanide. Having attended the court proceedings for 31 times, she was finally found guilty and got 20 years.

The National Police Headquarters Forensic Laboratory Center has also released the results of examining coffee samples taken by Wayan Mirna Salihin. From the coffee sample, it was found 15 grams of cyanide poison. In comparison, 90 milligrams of cyanide can cause death in people weighing 60 kilograms. Around 90 milligrams, if it is in liquid form, it takes only 3-4 drops; whereas 15 grams, it takes about one teaspoon (Wikipedia, 2016).

Barik (1992) and Hairuo (2015) systematized seven types of causes of errors in interpreting problems; nervousness, lack of practice, time pressure, speaking skill, classmates, tape recorders quality, and bad health. Such categorization was then developed differently by Gonzales : literal translation, inadequate language proficiency as grammar and lexicon, register conservation, distortion, addition, omission, protocol-procedure-ethics, and non-conservation of paralinguistic features.

Having briefly narrated the chronologies of Wayan Mirna Salihin's homicide hereabove, it is assumed that the issues related to the error-analysis interpreting, the likelihood of the errors made by interpreters, the inaccurate interpretion of the topics delivered by one person to another one, allegedly happened during the trial court which naturally came from source language to target language. Since interpreting process was held directly and the mistakes of the interpretation were detected by researchers during the initial observation, the research will eventually be intended to analyze the incorrectness of the interpretation being made from Jessica's case at the courtroom.

\section{Literature Review}

\subsection{Three Modes of Interpretation}

Error analysis is the avenue to spot grammatical, semantic, and phonological discrepancies and erroneous with the particular levels. In the academic setting, teachers of foreign language can apply them to detect the any error made by their students. Error analysis is an activity to reveal errors found in writing and speaking.

Error analysis is the process of observation, analysis, and classification of the deviations of the rules and regulation of the second language and then to reveal the systems operated by learner.

In this research, the source and target languages are divided into two namely English and Indonesian. The arrangements are organized as follows:

Part 1.

Source Language $\longrightarrow$ Toxicologist and Forensic Pathologist (English)

Target Language $\longrightarrow$ Interpreter (Indonesian)

Part 2.

Source language $\longrightarrow$ General Prosecutor and Jessica's Attorney (Indonesian)

Target Language $\longrightarrow$ Interpreter (English)

When it comes to mode of interpretation, the categorization is made based on the features of interactions: simultaneous interpretation, consecutive interpretation, and sight translation. The second one will be further discussed and implemented in this research. 
2.1.1 Simultaneous interpreting is when interpreter gets behind speaker from source language, transferring message toward target language nearly at same time the source language is being said. In judicial regulations, being simultaneous frequently happens in the situation where English is transferred into the other languages. This mode is usually processed in the heavily embroiled speaking with judges or attorneys, such as instructions of jury, and motions or arrangements. Unlike in the other type of interpreting, this natural flow of the speaker is not disturbed and allowed for a somewhat smooth output for the listeners.

2.1.2 Consecutive interpetation $(\mathbf{C l})$, is the process of listening in source language first, after that, meaning is delivered toward the target language. Usually length of words can be 40-60 at a time. $\mathrm{Cl}$ is commonly used interpreting from plaintiff with limited english speaking or proficiency mostly happening in attorney interwiews or may be client. Quickness in delivering information and difficulty of subject matter or speech's lenght will change depending on speaker, needing interpreter not only listening delivered orations but also processing dissimilar types and levels of discourse. The information or content which can be unpredictabled also making interpreter have a wide scope in vocabulary and high quality of delivering meaning toward source-target languages.

2.1.3 Sight translation is done before an interpreter proceeds to deliver the meaning from the written documents or letter set forward to the court by the oral interpretation; they have been standardized in the rights forms of waiver, the forms of driving under the influence of drugs or alcohol, and the reposts of police. In many routine procedures, the sight translation of such documents is performed in such a way that a defendant who is limited in English skill or proficiency will be able to comprehend. Sometimes, either formal or informal documents from a particular foreign language are presented and must be interpreted for the the sake of the court's benefit by the interpreter. Even though the opportunity might be provided to an interpreter to review the last document to show sight translation, it must be read first to anticipate from the incompleteness of the entire text in the content. The same level with simultaneous interpreting, sight translation needs interpreter to use skills of predicting in order to process information and make context for incomplete message or meaning.

Reading ahead and processing upcoming or next information are often done by interpreters at the moment they are delivering the units in the text. The function of interpreter is important and essential since they have a pivotal responsibility. This is analogized as a bridge of court and litigant who cannot speak English or other languages well. This leads them to convey the essense or meaning of a message and they are considered as the representation of all the voices of the participants in the courtroom.

\subsection{Types of Error in Consecutive Interpreting}

Types of Error in $\mathrm{Cl}$ are essential to systematize the report of discrepancies of the interpretation. Some of them are divided into eight various conditions: literal translation, inadequate language proficiency grammatically and lexically, register conservation, distortion, additions, omissions, protocol-procedures and ethics, and the last is non conservation paralinguistic features, (Gonzales, 1996, Barik, 1998, Hairuo,2015). 
Errors in Consecutive Interpreting: A Case of Jessica Kumalawongso's Court, Putri Pridani Malau, Syahron Lubis, Umar Mono

1. Literal translation. Barik (1998) states that interpreter only focuses on the substitute words from source language toward target language.

2. Inadequate language proficiency. It is simply the condition that an interpreter has lack of ability in predicting language patterns in sentences and expressions. It is divided into two types of error: lexical error and incorrect translation. The former is defined as the distortion and misunderstanding of the words meaning, while the latter is that an interpreter is unable to tell the message to the target language from source language.

3. Register conservation. It is the formality in speech which can take place in any situation such as courtroom, classroom also social event.

4. Distortion. It is about making the meaning lost. This one is integrated with three factors, deficient language skill, second memory, and interpretation skill.

5. Omission. This is the situation where the interpreter can delete information. Barik (1971) divides it into four types:

- Skipping omission. Interpreter deletes a word or short phrase which cannot change a structure; so in court interpreting, interpreter makes fault, explaining the target or source language toward public prosecutor of the court and toxicologist.

- Comprehension omission. An interpreter is unable to undesrtand some parts in the text which consequently causes the loss in meaning.

- Compounding omission. The interpreter composites two sentences by deleting some phrases.

6. Addition. This is the condition where an interpreter adds some information in delivering message to clients. These types are explained to have four kinds of condition such as:

- Qualifier addition is when an interpreter adds adjective or adverbs which don't exist in the source language. Barik ( 1971) states that interpreter can interpret the language with adding adjective or adverb in target language which does not exist in the source language.

- Elaboration addition is when an interpreter devotes some unconnected informationwhich consequently can little bit alter the meaning.

- Relationship addition is when an interpreter adds some of outside conjunctions in source language.

- Closure addition is when an interpreter can rephrase, omit and misinterpretate part in the target language and give the closure as well to the unit of the sentence, without adding anything substantial to it.

7. Protocol-procedures-ethics is the assumption that the message has a profanity which consequently takes the correction especially when the case is being tried in formal section.

8. Non-conservation of paralinguistic feature is the sentences which have filler,incompleteness, and repeated words and phrases.

- filler happens when interpreter making sounds "euu, $\mathrm{hm}$ ".

This happens because the interpreter makes pauses and the impact will have some sentence incompleted

- incomplete sentence is produced when a students is feeling under pressure at the moment of their interpretation, the not fulfilled idea, and lacked vocabulary leading them to the difficulty in expressing ideas.

- repeated words or phrases is little repetition in activiy of interpreting which can affect speech fluency. The impact will confuse the speech sounds and distracted product of interpretation. 
Language Literacy: Journal of Linguistics, Literature and Language Teaching

Volume 5, Number 1, pp: 71-79, June 2021

e-ISSN: 2580-9962 | p-ISSN: 2580-8672

DOI: $10.30743 / I I . v 5 i 1.2611$

\subsubsection{Interpreting Problems}

There are seven types of problems in interpreting such as nervousness, lack of practice, time pressure, speaking skill, classmates, bad tape and tape recorders quality. Furthermore, Ribas (2012) divides it into four types only: listening-understanding, note-taking, decoding notes and expressing-reformulating.

\subsubsection{Liason Interpreting}

Liason interpreting is when interpreter can express strong view in professional needs including provision in preparation material to the assignrment and physical working during the assignment (Hale, 2011).

Examples of the case in consecutive interpreting are shown in the table below:

\begin{tabular}{|c|c|c|}
\hline $\begin{array}{c}\text { Source Language } \\
\text { (Forensic Pathologist) }\end{array}$ & $\begin{array}{l}\text { Target Language } \\
\text { (Interpreter) }\end{array}$ & Types of Errors \\
\hline $\begin{array}{l}\text { 1. I } 1 \text { would expect the } \\
\text { formalin in the blood } \\
\text { stream. }\end{array}$ & $\begin{array}{l}1.2 \text { euu. } 1 \text { Tentunya } \\
\text { formalin tersebut akan } \\
\text { masuk ke dalam aliran } \\
\text { darah. }\end{array}$ & $\begin{array}{l}{ }_{1} \text { Incorrect meaning. } \\
{ }_{2} \text { Filler } \\
{ }_{1} \text { Incorrect interpretation }\end{array}$ \\
\hline $\begin{array}{l}\text { 2. And it } 1 \text { actually low levels, } \\
2 \text { for my sure is normally } \\
\text { low levels. }\end{array}$ & $\begin{array}{l}\text { 2. dan } 1 \text { biasanya sianida } \\
\text { yang terbentuk itu sedikit. }\end{array}$ & ${ }_{2}$ Comprehension omission \\
\hline
\end{tabular}

Based on the first example, the interpreter makes "euu" once in one sentence. The case during the pause is more than five seconds and could be recognized by the audience because it is annoying. It should have been 'saya berekspektasi' not 'tentunya'. The errors in the second example show incorrect interpretation and comprehension omission. The interpreter fails to deliver the meaning 'actually' in target language which is supposed to be 'sebenarnya' but the interpreter says 'biasanya' which has confused meaning. The clause 'for my sure' is deleted in that sentence whereas the meaning in the target language is 'saya yakin'.

\section{Research Method}

The research method covers identification, classification, interpretation, and finding a solution. Interpreting is the part of analysis and conclusion. The flowchart below simplifies the explanation of the methodological steps (Mahsun, 2005).

Identification $\longrightarrow$ Classification $\longrightarrow$ Analysis $\longrightarrow$ Conclusion

The first one is identifying the source of data. Then, it is followed with classifying the collected data according to the types of errors in consecutive interpreting. The next one is analyzing the types of errors in consecutive interpreting. And the last is concluding the data to make the dominant type of error in consecutive interpreting. The final objective is to find the causes of the errors or interpreting problems in consecutive interpreting in Jessica Kumalawongso's court.

\section{Results and Discussion}

\subsection{The first video: Expert: The cause of Mirna's death is not cyanide}

The data are arranged based on the detected errors in the first video expert: The cause of Mirna's death is not cyanide. Six main types of errors are indicated such as register 
Errors in Consecutive Interpreting: A Case of Jessica Kumalawongso's Court, Putri Pridani Malau, Syahron Lubis, Umar Mono

conservation, non conservation of paralinguistic feature, addition, omission, inadequate language proficiency, and distortion.

The eight subtypes of error based on four main types; the first is addition which has four subtypes, consisting of addition in qualifier, relationship, closure and elaboration. Second it is omission which has one subtype, consisting of skipping omission. The third is nonconservation of paralinguistic feature which has two subtypes, consisting of filler and repeated phrase or word. And the fourth is inadequate language proficiency which has one subtype, that is incorrect interpretation.

The explanation is systematically scrutinized in the table below. Two other main types with no subtype: register conservation and distortion are detected. Thoroughly, the finding of errors in consecutive interpreting in the first video entitled Expert: The cause of Mirna's death is not cyanide are 44 errors.

\begin{tabular}{|l|l|l|c|}
\hline \multirow{2}{*}{ Number } & \multicolumn{1}{|c|}{$\begin{array}{c}\text { Main Types } \\
\text { of Error }\end{array}$} & \multicolumn{1}{|c|}{ Sub Types of Error } & Quantity \\
\hline 1. & Register Conservation & - & 7 \\
\hline \multirow{3}{*}{2.} & \multirow{2}{*}{ Addition } & Qualifier addition & 6 \\
\cline { 3 - 4 } & & Elaboration addition & 1 \\
\cline { 2 - 4 } & Closure addition & 1 \\
\cline { 2 - 4 } & Relationship addition & 7 \\
\hline 3. & Omission & Skipping omission & 2 \\
\hline \multirow{2}{*}{4.} & $\begin{array}{l}\text { Non-conservation of paralinguistic } \\
\text { feature }\end{array}$ & Filler & 6 \\
\cline { 2 - 4 } & Repeated phrase/word & 9 \\
\hline 6. & Inadequate language proficiency & Incorrect interpretation & 4 \\
\hline Total & Distortion & - & $\mathbf{4 4}$ \\
\hline
\end{tabular}

\subsection{The second video: Australian Witness Considers Other Causes of Mirna's Death}

From the second video, four main types of error are found, consisting of addition, omission, non conservation of paralinguistic feature, and inadequate language proficiency. Meanwhile, seven error subtypes of fourth main types are indicated: non-conservation of paralinguistic feature is the first one which has two subtypes: filler and repeated phrase. The second one is addition which has four subtypes, The indicated ones are relationship addition and elaboration addition. The third is inadequate language proficiency which has two subtypes and both are present : incorrect interpretation and lexical error. The fourth one is omission which has one subtype, comprehension omission.

The data are elaborated and described in the table below. Apparently, the numbers of errors in the $\mathrm{Cl}$ spotted in the second video entitled Australian Witness Considers Other Causes of Mirna's Death are as many as seven.

\begin{tabular}{|c|c|c|c|}
\hline Number & $\begin{array}{l}\text { Main Types } \\
\text { of Error }\end{array}$ & Sub Types of Error & Quantity \\
\hline \multirow{2}{*}{1.} & \multirow{2}{*}{$\begin{array}{l}\text { Non-conservation of } \\
\text { paralinguistic feature }\end{array}$} & Repeated phrase & 1 \\
\hline & & Filler & 1 \\
\hline \multirow{2}{*}{2.} & \multirow{2}{*}{ Addition } & Relationship addition & 1 \\
\hline & & Elaboration addition & 1 \\
\hline
\end{tabular}


Language Literacy: Journal of Linguistics, Literature and Language Teaching

Volume 5, Number 1, pp: 71-79, June 2021

e-ISSN: 2580-9962 | p-ISSN: 2580-8672

DOI: $10.30743 / I I . v 5 i 1.2611$

\begin{tabular}{|l|l|l|c|}
\hline \multirow{2}{*}{3.} & \multirow{2}{*}{$\begin{array}{l}\text { Inadequate language } \\
\text { proficiency }\end{array}$} & Incorrect interpretation & 1 \\
\cline { 3 - 4 } & Oexical errors & 1 \\
\hline 4. & Omission & Comprehension omission & 1 \\
\hline
\end{tabular}

\subsection{The third video: Expert: Cyanide is Broken Down by Formalin in Mirna's Body}

The first video is entitled: Expert: The cause of Mirna's death is not cyanide. In the third one five major types of errors are found consisting of inadequate language proficiencies, non conservation of paralinguistic feature, omission, distortion, and addition.

The seven subtypes of error are originally derived from four main types. The first one is the inadequate language proficiency which has one subtype and consists of the incorrect interpretation. The second one is the non-conservation of paralinguistic feature which has two subtypes and consists of filler and repeated phrase. The third one is omission which has two subtypes and consists of the comprehension omission and skipping omission. The fourth one is the addition which has the addition of qualifier and of elaboration. The last one is the omission which has one subtype and consists of the comprehension omission.

The details are scrutinized in the table below along with the other main type without subtype which is called distortion. Hence, errors found in consecutive interpreting from the case of Jessica Kumalawongso's court in the third video are entitled Expert: Cyanide is Broke Down by Formalin in Mirna's Body are as many as 16 altogether.

\begin{tabular}{|c|c|c|c|}
\hline Number & $\begin{array}{l}\text { Main Types } \\
\text { of Error }\end{array}$ & Sub Types of Error & Quantity \\
\hline 1. & Inadequate language proficiency & Incorrect interpretation & 4 \\
\hline \multirow{2}{*}{2.} & \multirow{2}{*}{$\begin{array}{l}\text { Non-conservation } \\
\text { paralinguistic feature }\end{array}$} & Filler & 1 \\
\hline & & Repeated phrase & 2 \\
\hline \multirow[t]{2}{*}{3.} & \multirow[t]{2}{*}{ Omission } & $\begin{array}{l}\text { Comprehension } \\
\text { omission }\end{array}$ & 3 \\
\hline & & Skipping omission & 1 \\
\hline 4. & Distortion & - & 1 \\
\hline \multirow{2}{*}{5.} & \multirow{2}{*}{ Addition } & Qualifier addition & 3 \\
\hline & & Elaboration addition & 1 \\
\hline \multicolumn{3}{|l|}{ Total } & 16 \\
\hline
\end{tabular}

Overall, 67 errors are found from the three videos of Jessica Kumalawongso's court with six out of eight main types of errors based on the theory of Gonzales in consecutive interpreting. Among others, they consist of non conservation of paralinguistic features, inadequate language proficiencies, addition, omission, distortion, and register conservation.

\subsection{Discussion}

This part explains the errors in accordance to Gonzales' theory, and the comparison of the current findings to others which have described the similar case. Below are the one between this research and the other findings studied by Rully Sutrirasa Pratiwi (I), that has been previously published in Sutri's Journal from University of Indonesia. The similar findings are apparently found from hers (I) and the current one (II). 
Errors in Consecutive Interpreting: A Case of Jessica Kumalawongso's Court, Putri Pridani Malau, Syahron Lubis, Umar Mono

(I)

(II)

\begin{tabular}{|c|c|c|c|c|c|}
\hline $\begin{array}{c}\text { Source } \\
\text { Language } \\
\text { (English) } \\
\text { Speaker }\end{array}$ & $\begin{array}{c}\text { Target } \\
\text { Language } \\
\text { (Indonesia) } \\
\text { Interpreter }\end{array}$ & Type oferror & $\begin{array}{c}\text { Source } \\
\text { Language } \\
\text { (Forensic } \\
\text { Pathologist) }\end{array}$ & $\begin{array}{c}\text { Target } \\
\text { Language } \\
\text { (Interpreter) }\end{array}$ & $\begin{array}{l}\text { Types of } \\
\text { Errors }\end{array}$ \\
\hline $\begin{array}{l}\text { 1. Can you, } \\
\text { recommend } \\
\text { me the good } \\
\text { place for me to } \\
\text { have a } \\
\text { honeymoon in } \\
\text { 1Bandung? }\end{array}$ & $\begin{array}{l}\text { Euu.. Apakah } \\
\text { mas Robi, } \\
\text { punya } \\
\text { rekomenda si } \\
\text { tempat yang } \\
\text { cocok untuk } \\
\text { bulan madu? }\end{array}$ & $\begin{array}{l}\text { 1Skipping } \\
\text { omission. }\end{array}$ & $\begin{array}{l}\text { 1. No } 1 \text { post } \\
\text { mortem } \\
\text { finding of } \\
\text { 2cyanide } \\
\text { toxicity. }\end{array}$ & $\begin{array}{l}\text { Tidak } \\
\text { ditemukan } \\
\text { adanya } \\
\text { toksisitas } \\
\text { 3eeu...1pada } \\
\text { perubahan } \\
\text { pasca } \\
\text { kematian. }\end{array}$ & $\begin{array}{l}\text { 1 Incorrect } \\
\text { Interpretation } \\
{ }_{2} \text { Skipping } \\
\text { omission } \\
{ }_{3} \text { Filler }\end{array}$ \\
\hline $\begin{array}{l}\text { 2. } 1 \text { Nice to meet } \\
\text { you, my name } \\
\text { is Divta.... }\end{array}$ & $\begin{array}{l}{ }_{2}^{2 E u U . . ~ Y a, ~ n a m a ~} \\
\text { saya Divta }\end{array}$ & $\begin{array}{l}{ }_{1} \text { Comprehensi } \\
\text { on omission } \\
{ }_{2} \text { Filler }\end{array}$ & $\begin{array}{l}\text { 2. } 1 \text { So, one is that } \\
\text { the clinical } \\
\text { presentat.. } \\
2 \frac{\text { eeu... sorry, }}{\text { clinicalspresent }} \\
\frac{\text { ation is not a }}{\text { typical }}\end{array}$ & $\begin{array}{l}\text { Adalah bahwa } \\
\text { pertama shasil } \\
\text { pemeriksaan } \\
\text { klinistidaklah } \\
\text { khas untuk } \\
\text { 4keracunan } \\
\text { sianida }\end{array}$ & $\begin{array}{l}{ }_{1} \text { Qualifier } \\
\text { addition } \\
{ }_{2} \text { Filler } \\
{ }_{3} \text { Register } \\
\text { Conservation } \\
{ }_{4} \text { Closure } \\
\text { addition }\end{array}$ \\
\hline $\begin{array}{l}\text { 3. To find a new } \\
\text { talent and new } \\
\text { enternainer. }\end{array}$ & $\begin{array}{l}1 \text { Euu.. disini } \\
\text { saya sedang } \\
\text { mencari talent } \\
\text { dan entertainer } \\
\text { yang } 2 \text { berbakat }\end{array}$ & $\begin{array}{l}{ }_{1} \text { Filler } \\
{ }_{2} \text { Qualifier } \\
\text { addition }\end{array}$ & $\begin{array}{l}\text { 3. That is not due } \\
\text { to cyanide as } \\
1 \text { reasoning }\end{array}$ & $\begin{array}{l}\text { Ini bukan } \\
{ }_{1} \text { diakibatkan } \\
\text { oleh } \\
\text { 2keracunan } \\
\text { sianida }\end{array}$ & $\begin{array}{l}{ }_{1} \text { Register } \\
\text { Conservation } \\
{ }_{2} \text { Qualifier } \\
\text { addition }\end{array}$ \\
\hline 4. I will see it first. & $\begin{array}{lr}\text { Ya, } & \text { mungkin } \\
\text { saya } \quad \text { bisa } \\
\text { melihat dulu } 1 \text { ya } \\
\text { bu yang tari-tari } \\
\text { an itu. }\end{array}$ & $\begin{array}{l}\text { 1Elaboration } \\
\text { addition. }\end{array}$ & $\begin{array}{l}\text { 4. That is, } 1 \text { that is } \\
\text { the red as } \\
\text { coloration }\end{array}$ & $\begin{array}{l}\underline{2 \text { Seperti }} \\
\text { misalnya } \\
\text { warna } \\
\text { beeu.. } \\
\text { berubah } \\
\text { menjadi } \\
\text { terang }\end{array}$ & $\begin{array}{l}{ }_{1} \text { Register } \\
\text { Conservation } \\
{ }_{2} \text { Elaboration } \\
\text { addition } \\
{ }_{3} \text { Filler }\end{array}$ \\
\hline
\end{tabular}

\section{Conclusion}

There are 10 subtypes of error under four main types; the first one is non-conservation of paralinguistic feature which has two subtypes : filler and repeated phrase or word. The second one is the inadequate language proficiency which has two subtypes consisting of incorrect interpretation and lexical error. The third one is addition which has four subtypes consisting of the addition in qualifier, relationship, closure and elaboration. The last one is the omission which has two subtypes: skipping omission and comprehension omission. Two other main types with no subtype are register conservation and distortion.

To sum up, based on the theory of Gonzales, there are six out of eight main types of errors in consecutive interpreting detected from three videos of Jessica Kumalawongso's court. They consist of non conservation of paralinguistic features, addition, omission, inadequate language proficienies, distortion and register conservation.

\section{References}

Bao, B. T. (1997). Dang Xuan Thu and Interpreting -Translation Section. Vietnam: Hanoi University of Foreign Studies. 
Barik, H. (1997). A description of various types of omission, additions, and errors of translation encountered in simultaneous interpretation. Meta Translations' Journal, 199-210.

Gonzales, Rosean Duenas, et.al. (1996). Fundamentals of Court Interpretation. Theory, Policy and Practice. North Carolina: Caroline Academic Press.

Hale, S. (2011). Interpreter policies, practices and protocols in Australian Courts and Tribunals A national survey. Melbourne CBD: The Australasian Institute of Judicial Administration Incorporated, Minuted Man Press.

Hale, S. (2014). Perspectives: Studies in Translatology, Interpreting culture. Dealing with cross-cultural issues in court interpreting. Faculty of Arts and Social Sciences, University of New South Wales, Sydney, NSW, Australia: Routledge Informa Ltd. Vol. 22, No. 3, 321331, http://dx.doi.org/10.1080/0907676X.2013.827226.

Hairuo, W. (2015). Error Analysis in Consecutive Interpeting of Students with Chinese in English Language Pairs. Canada: CSCanada. Canadian Social Science Vol. 11, No. 11, pp. 65-79 DOI:10.3968/7755.

Mahsun, M.S. (2005). Metode Penelitian Bahasa: Tahapan strategi, metode dan tekniknya. Jakarta: Raya Grafindo.

Pratiwi, R. S. (2016). Common Errors and Problems Encountered By Students English To Indonesian Consecutive Interpreting. Department of English Education, Indonesia University of Education. Journal of English and Education 2016, 4(1), 127-146.

Ribas, M. A. (2012). Problems and strategies in consecutive interpreting: a pilot study at two different stages of interpreter training. Barcelona, Spain: Universitat Autonoma de Barcelona. 7(3). 813-835.

Russell, D. et.al. (2011). Consecutive Interpreting. Canada: University of Alberta.Dir://integrafs1/kcg/2Pagination/TandF/RHI_RAPS/ApplicationFiles/9780415 811668_text.3d.

Youtube, (2016). Ahli: Penyebab Kematian Mirna Bukan Sianida, Saksi Australia Pertimbangkan Penyebab Lain Mirna Meninggal, Ahli: Sianida Terurai oleh Formalin di Tubuh Mirna. Jakarta: Kompas TV. https://www.youtube.com/watch?v=ygINCz1LeeM; https://www.youtube.com/watch?v=sA1gT_Rcz_k; https://www.youtube.com/watch?v=CeYAll1 $1 \mathrm{KgVc}$.

Wikipedia. https://id.wikipedia.org/wiki/Pembunuhan_Wayan_Mirna_Salihin 